\title{
Working Faculties: Education of People's Masses and/ or Ideology Driven Chimera
}

\author{
Vadim Zubov \\ Financial University under the Government of Russian Federation \\ Moscow, Russia \\ E-mail: zubov305@yandex.ru
}

\begin{abstract}
The paper presents the history of the creation and development of the Workers' Faculties in the Russian SFSR and the USSR, whose system became widespread in the first fifteen years of the existence of the Soviet state. The stages of development of the Workers' Faculties are distinguished. Special attention in the article is paid to the legislation regulating the activities of the Workers' Faculties. Theoretical views on the functioning of the Workers' Faculties and their role in the Soviet system of higher education are investigated. The consequences of the application of this educational model are analyzed.
\end{abstract}

Keywords-Workers' Faculties; educational system; communist ideology; enlightenment; Soviet justice; higher education

\section{INTRODUCTION}

The problem of a shortage of qualified personnel was acutely faced by the leadership of the young Soviet state from the first days of its existence. The core members of the Bolshevik Party, which played a key role in the events of October 1917 and occupied a dominant position in the government of the Russian SFSR, were experienced revolutionaries, most of them were capable of carrying out effective management and conducting ideological work within the framework of their ideology. However, building a full-fledged state required personnel capable of solving various tasks, the implementation of which demanded knowledge in the field of natural and technical sciences. Bolsheviks could not fully rely on the old technical "intelligentsia", which, due to the estate system of the Russian Empire, was rather small in number and did not feel much sympathy for the new government. The leaders of Soviet Russia supposed to solve this problem utilizing loyal people from the former underprivileged classes: the workers and peasants. To implement the ideas of the Bolsheviks in practice to eliminate the barriers that existed in the prerevolutionary education system, and the fundamentally new educational sites for the semiliterate population, whose role was to be carried out by the Workers' Faculties, had to be created.

\section{ESTABLISHMENT OF WORKERS' FACULTIES AND SECURING THEIR STATUS IN LEGISLATION}

Large-scale changes in education, which the Bolsheviks planned to conduct, began with the elimination of the old system of education: in May 1918, a decision of the People's Commissariat of Enlightenment was issued, introducing coeducation of students of both genders [1]. Three months later, the Council of People's Commissars issued a decree setting the rules for admission to higher educational institutions [2]. The new rules gave the right to admission to all persons who have reached the age of 16 and who had an identity card confirming their age. The requirements to provide a graduation certificate, competitive exams, and tuition fees were annulled. Foreign citizens were also eligible for admission without any restrictions. This decree radically changed the traditions of higher education in Russia that took shape over the years. Such revolutionary measures, which obviously could not be fully implemented, opened the way for the creation of Workers' Faculties — the first compromise between the ideology of the new government and the educational process in practice.

Under conditions of the growing Civil War, the Bolsheviks could not pay enough attention to the problems of education, therefore the creation and formalization of the intermediate link between the higher education institution and the person who was trying to get an education was delayed for more than a year. In September 1919, a decree of the People's Commissariat of Enlightenment was issued, which provided for the organization of Workers' Faculties at universities [3]. This document is an extremely informative source for several reasons:

- In the preamble of the resolution, the necessity of creating Workers' Faculties is substantiated, since the ideas embodied in the decree of the Council of People's Commissars of August 1918 made it possible that an illiterate person could become a student of any higher educational institution on completely legal basis. It is emphasized that an obstacle to the realization of the right of the proletarian masses to education is the "lack of preparedness in the subjects of exact knowledge".

- The definition of the Workers' Faculties, which are defined as "preparatory courses, as autonomous 
educational and auxiliary institutions with the aim of preparing workers and peasants for high school in shortest term", which will be opened at universities of the Russian SFSR, is given.

- The structure of the Workers' Faculties and the procedure for their material support is established. The status of "autonomous educational supportive institutions" gave them extremely ample opportunities to use the material base of universities and their teaching staff.

- The admission parameters are clarified: workers and peasants who are obliged to provide a certificate issued by the factory committee or the communist cell about membership in the above-mentioned social classes and loyalty to Soviet power have the right to enroll.

It seems that there is a contradiction in this regulatory legal act which will be inherent in most of the documents of the Soviet state concerning educational issues: on the one hand, it was assumed that the preparation of workers and peasants for higher education should take place in shortest terms but, on the other hand, the requests on the intellectual abilities of potential students were not submitted, the absence of these initially called into question the quality of future graduates of the Workers' Faculties. At the same time, two criteria began to play a key role: the level of external support for the current government and the "right" social origin.

After the partial stabilization of the situation in the country, the status of the Workers' Faculties was determined at the highest level: in September 1920, the Council of People's Commissars issued the decree "On Workers' Faculties" [4]. Without introducing fundamental innovations, it nevertheless laconically formulated the task of the Workers' Faculties as "the extensive involvement of the proletarian and peasant masses in the walls of the Higher School". It may be noted that the text of the decree contains many ideological clichés, for example: "enhanced work", "strictest control", which emphasized the high importance of the Workers' Faculties and the deep interest of the Soviet government in their successful implementation. It should be borne in mind that the decree refers to the legislative acts of the times of the policy of War Communism, under which students of Workers' Faculties were regarded as citizens who were obliged to bear educational service by analogy with the labor armies then in force. The publication of this act finally regularized the Workers' Faculties as one of the main instruments for building a new society, on which the country's leadership could rely in implementing its ambitious plans.

\section{FUNCTIONING OF WORKERS' FACULTIES}

After the Bolsheviks established control over most of the Russian Empire, and the War Communism policy was replaced by the New Economic Policy period, the political leadership had the opportunity to analyze the situation in the field of education and draw certain conclusions based on data obtained during the first years of the Soviet state's existence. The emergence of a large number of specialized printed media contributed to the intensification of public debate about the possible ways of development of the country. Workers' Faculties also received their own media the "Bulletin of Workers' Faculties" journal. At the beginning of 1921, the article by the People's Commissar for Education, A. V. Lunacharsky, "The Role of the Workers' Faculties", appeared in it, which anticipated future discussions about the role of the Workers' Faculties and in its own way foresaw their future development [5].

In his article, Lunacharsky points out that the creation of the Workers' Faculties had three fundamental reasons:

Firstly, the revolutionary events caused serious damage to educational institutions at all levels of education, while the "second stage schools" suffered the most (upper secondary schools and non-classical secondary schools). Lunacharsky emphasizes that their teaching staff was negatively predisposed towards the new regime, which relied on the large number of teachers put in their places by the tsarist authorities and with the political beliefs of the latter, which he defines as "Cadet" and "Social Revolutionary". He cites a negative example of Soviet Ukraine, where upper secondary schools and non-classical secondary schools were abolished, which caused serious damage to the continuity of the educational process. Secondary school in the Russian SFSR suffered to a lesser extent than in Ukraine, however, according to the author, there was a huge gap between the new generation of potential applicants (suitable for age, but not for education) and universities, which finally prompted the Bolsheviks to let "applicants from outside" enroll, obviously, could not cope with the program of higher educational institutions without due preparation. Thus, the Workers' Faculties were to become quasi-upper secondary schools and quasi-non-classical secondary schools, which had the task of preventing a collapse similar to that which occurred on the territory of Soviet Ukraine.

Secondly, the Workers' Faculties, which, according to Lunacharsky, were an integral part of higher educational institutions (which complied with the current legislation at that time), that would act as the main lever of influence on the university environment with a view to its "proletarianization". He cites the positive and negative aspects of this process: on the one hand, "proletarization" (which, according to Lunacharsky, has paramount importance) will lead to the emergence of professional proletarian specialists, which he regards as a big advantage for university education in general, on the other hand, lack of barriers lead to the fact that higher education institutions were overwhelmed with workers of various abilities and motivations, some of them disappointed in their abilities and leave, and a certain number of such students remain, confronted with political activities with a conventional attitude to classes. Lunacharsky believes that local party organizations must be more careful in their selection of candidates for educating and give an advantage to those who have the desire to study and who already have some background. At the same time, he still gives preference to the "gifted and able to assimilate the knowledge in essence" persons than to those whose "formal literacy" is higher. It 
seems that this judgment in a mild form emphasizes the need to find candidates of the "right" origin, which inevitably makes these selection criteria dependent also on local arbitrariness.

Third, Workers' Faculties, being preparatory courses before receiving higher education, should change not only the class origin of students, but also change the very method of teaching, shifting the focus towards practical training combined with theory. Lunacharsky was sure that yesterday's upper secondary school student loses in his personal qualities to a professional worker who not only successfully masters the educational course (technical sciences are implied), but also influences his teachers getting them used to new education methods.

Summing up, Lunacharsky urges the Workers' Faculties, which, in his opinion, are in the process of natural growth, "must not crush and injure normal organs, normal higher education institutions", and the universities, in turn, must not hinder their performance, since Workers' Faculties are the future of universities.

When analyzing the article of Lunacharsky, three fundamental bases (main roles) can be summarized briefly: Workers' Faculties are the "door" to the university, Workers' Faculties are an instrument to subordinate the university, Workers' Faculties are the initiator of the university's qualitative change. Using verbs, it turns out: enter, capture, transform.

\section{DEVELOPMENT OF WORKERS' FACULTIES AND THE RESUlTS OF THEIR ACTIVITY}

According to statistics, as of January 1, 1924, there were 133 Workers' Faculties in the Soviet Union, in which 45,000 students studied [6]. It stands to mention that in the first years of the existence of the Workers' Faculties there was a strong rejection of the "red" students by some professors and "old" students whose worldview was formed before the Russian revolution, which in turn caused a response from the students of the Workers' Faculties, who treated their opponents as the alien elements for the new society. At the same time high motivation of new students and their deep immersion in study was mentioned [7]. It can be stated that the New Economic Policy period to a certain extent slowed down the movement towards building a new type of education system: the political leadership was involved in a tough struggle within the party, various forces offered many options for the country's future development, and politicians could change their ideological platform several times. Under these conditions, by 1928, there were 147 Workers' Faculties in the country, in which 49,000 students studied [8].

New impetus to the development of the Workers' Faculties was given by industrialization and a sharp increase in the number of higher educational institutions that occurred during the first five-year plan: in 1933 there were 926 Workers' Faculties in the country, in which 352,000 students studied. In 1930, a joint Resolution was issued by the Central Executive Committee and the Council of People's Commissars on the reorganization of higher educational institutions, training colleges and Workers' Faculties [9].
The ideas expressed in 1921 by Lunacharsky were tried to be put into practice using the administrative apparatus created in the preceding decade. It was assumed that a Workers' Faculties should be created at each higher education institution. It was also envisaged to develop a plan for the development of a network of evening and afternoon Workers' Faculties. However, these transformations seem to have significantly reduced the importance of the Workers' Faculties, which, according to Lunacharsky, were supposed to give a comprehensive education, which was extremely difficult in the conditions of the transformation of "multifaculty institutions of higher education" and training colleges into branch-wise ones. The situation with secondary education has also changed: the Soviet Union achieved significant success in building an effective system of secondary schools, which partially resolved the issue of the level of education of applicants originating from workers and peasants. For these reasons, by the mid-1930s, the Workers' Faculties ceased to exist [10].

It is obvious that already in 1921, Lunacharsky, as the main ideologist of the new Soviet education and the organizer of all key changes in this area, involuntarily emphasized that higher education institutions are "normal" (it is impossible to say with complete certainty what he meant by using the word "normal", as it could be used in the sense of "ordinary", "traditional"). Lunacharsky assumed that the role of the Workers' Faculties was not only to prepare yesterday's workers and peasants who expressed a desire to get higher education without the knowledge that before the revolution students received in upper secondary schools and non-classical secondary schools, but also to transform the learning process itself, creating a fundamentally new higher education institution, different from the classical university, the foundations of which were laid back in the Middle Ages.

It can be stated that the Workers' Faculties (and not only these and even rather than these) managed to fulfill two roles that Lunacharsky assigned to them: they managed to train personnel that later replaced the old technical intelligentsia in plants and factories, and to a greater degree changed the social composition of higher educational institutions (now, people from the former underprivileged classes, who made up the majority of the students, had access to these).However, the Workers' Faculties could not fulfill the third and most ambitious role: by the 1970s, the Soviet higher education institutions almost completely returned to the very same classical model of university functioning and students' behavior that Lunacharsky critically referred to: "a young man, drilled at cursed desks, heard a lecture, at least with attention, just to memorize it whenever possible" "unnecessary scholasticism, which is still largely mixed in with university education".

\section{CONCLUSION}

The Workers' Faculties failed to become the main instrument for transforming the society, but to a certain extent they turned out to be a test platform where many mechanisms were first tried, being generated by communist ideology first, and then by the internal features of the Soviet 
Union, then became typical of higher education and science, which always depended directly on higher education and ideally should have very close ties with the latter. Different, often polar, points of view are expressed (both critical [11] and glowing [12]) about the effectiveness and progressiveness of Soviet science and higher education (especially in the humanities). At the same time, it is safe to say that the goal set in 1920 (enlightenment of the masses) was achieved, but the question of the role of ideology in Soviet education is still open.

\section{REFERENCES}

[1] "Resolution of the National Commissariat of Enlightenment on the Introduction of Compulsory Joint Training" from 1918.05.31 No. 499 // Collection of Laws and Orders of the Government for 1917-1918. Administrative Office of the USSR Council of People's Commissars. M., 1942, p. 530.

[2] "Decree of the Council of People's Commissars. On the Rules of Admission to Higher Educational Institutions" dated 1918.08.02 No. 632 // Collection of Laws and Orders of the Government for 19171918. Administrative Office of the USSR Council of People's Commissars. M., 1942, p. 770.

[3] "Resolution of the National Commissariat of Enlightenment. On the Organization of Working Faculties at Universities" dated 1919.09.11 No. 443 // Collection of Laws and Orders of the Government for 1919. Administrative Office of the Council of People's Commissars of the USSR M., 1943 pp. 643-645.

[4] 'Decree of the Council of People's Commissars. On the Workers' Faculties" dated 1920.09.17 No. 381 // Collection of Laws and Orders of the Government for 1920. Administrative Office of the Council of People's Commissars of the USSR, 1943. p. 576.

[5] The Role of Working faculties. "Bulletin of the workers' faculties", 1921, No. 1, p. 3-7.

[6] Public Education in the USSR According to Current Surveys on January 1, 1922, 1923 and 1924. // Proceedings of the Central Statistical Office, Vol. XXVIII, issue 1, M., 1926, 1926. p. 435.

[7] A.F. Krivonozhenko. Workers' Faculties in the Context of the Paradigm of Continuing Education // Continuing Education: XXI century. 2016. № 3 (15). pp. 90-96.

[8] Culture, Personnel and Science // USSR in Figures (1934). Moscow: Soyuzorguchet, 1934. p. 131.

[9] Resolution of the Central Executive Committee and the Council of People's Commissars "On the Reorganization of Higher Educational Institutions, Training Schools and Workers' Faculties" dated 1930.07.23 No. 38, // Collection of Laws and Orders of the Workers 'and Peasants' Government of the USSR for 1930, p. 693-695

[10] T.A. Volkova. Workers' Faculties in the Practice of the Development of Soviet Higher education in the 1920s -1930s // Bulletin of Chuvash University. 2008. No. 4. pp. 11-17.

[11] P.Aven. Berezovsky Time. Moscow, 2017.816 p.

[12] Zh. Alfyorov. In a Global World, We Must Be Leaders! // "Arguments and Facts" Weekly. 2013.22.05. p. 13. 